\title{
Sığırlarda farklı pnömoni tiplerinde Tümör Nekroz Faktör Alfa (TNF $\alpha$ ), Malondialdehit (MDA), Prokalsitonin ve Neopterin düzeylerinin karşılaştırılması
}

\author{
Nevin Tuzcu' (), Mehmet Tuzcu² (), Gökhan Akçakavak³ () \\ ${ }^{1}$ Selçuk Üniversitesi Veteriner Fakültesi Mikrobiyoloji Anabilim Dalı, Konya, Türkiye. \\ 2,3 Selçuk Üniversitesi Veteriner Fakültesi Patoloji Anabilim Dalı, Konya, Türkiye.
}

Geliş Tarihi / Received: 01.04.2020, Kabul tarihi / Accepted:12.05.2020

\begin{abstract}
Özet: Pnömoniler, sığıllarda görülen mortalite ve morbiditenin temel nedenleri arasında sayılan, önemli bir akciğer hastalığıdır. Klinik olarak iştahsızlık, yüksek ateş, solunum güçlüğü, solunum sayısında artış ve burun akıntısı ile karakterizedir. Sığırların solunum yolu hastalıklarının sınıflandııılmasına yönelik yapılan çalışmalarda, fibrinli bronkopnömoniler, irinli bronkopnömoniler, interstisyel pnömoniler ve tüberkülozis ön plana çıkmaktadır. Bu çalışmada kesim sonrası alınan örnekler, makroskopik bulgulara göre her grupta 25 hayvana ait olmak üzere 4 guruba (fibrinli bronkopnömoni, irinli bronkopnömoni, interstisyel pnömoni ve tüberküloz pnömonisi) ayrıldı. Daha sonra her guruptan mikroskobik muayene ile doğrulanmış 8'er adet kan serumu ve akciğer dokusu alındı. Yapılan bu çalışmada sığılların tüberküloz pnömonilerinde tümör nekroz faktör alfanın (TNF $\alpha$ ) ve neopterinin, fibrinli brokopnömonilerinde malondialdehitin (MDA), irinli bronkopnömonilerde prokalsitoninin, interstisyel pnömonilerde ise neopterinin akciğer dokusunda ve kan serumunda istatistiki olarak anlamlı derecede yüksek olduğu belirlendi. Elde edilen sonuçlardan TNF $\alpha, M D A$, prokalsitonin ve neopterinin veteriner hekimlerin pnömonileri tiplendirmesine yardımcı olabileceği düşünülse de detaylı çalışmalara ihtiyaç olduğu kanaatine varılmıştır.
\end{abstract}

Anahtar kelimeler: Malondialdehit, Neopterin, Pnömoni, Prokalsitonin, Tümör Nekroz Faktör Alfa

\section{Comparison of Tumor Necrosis Factor Alpha (TNF $\alpha$ ), Malondialdehyde (MDA), Procalcitonin and Neopterin levels in Different pneumonia types in cattle}

\begin{abstract}
Pneumonia is an important lung disease that considered as one of the main causes of mortality and morbidity in cattle. It is clinically characterized by anorexia, high fever, dyspnea, increase the rate of inhaling and exhale of respiratory system and discharge of nose. Fibrinous bronchopneumonias, purulent bronchopneumonias, interstitial pneumonias and tuberculosis have been come to the fore in classification studies of respiratory diseases of cattle. In this study after slaughter samples were separated into 4 groups by based on macroscopic examination (fibrinous bronchopneumonia, purulent bronchopneumonia, interstitial pneumonia and tuberculosis pneumonia) each group consists of 25 cattle. Later, 8 blood serums and lung tissues were taken from each group were confirmed by microscopic examination. In this study, the tumor necrosis factor alpha (TNF $\alpha$ ) and neopterin of tuberculosis pneumonias, malondialdehyde (MDA) of fibrinous bronchopneumonias, procalcitonin of pulmonary bronchopneumonias, and neopterin of interstitial pneumonias were statistically found to be significantly higher in both of lung tissues and sera of cattle. It was though that, although TNF $\alpha$, MDA, procalcitonin and neopterin can help veterinarians to type pneumonia, comprehensive studies are needed.
\end{abstract}

Key words: Malondialdehit, Neopterin, Pneumonia, Procalcitonin, Tumor necrosis factor alpha

\section{Giriş}

Pnömoniler klinik olarak iştahsızlık, yüksek ateş, solunum güçlüğü, solunum sayısında artış ve burun akıntısı ile karakterizedir (Lopez ve ark. 2017). Pnömonide oluşan lezyonlar, etkenin türüne, akciğere giriş yoluna, hayvanın yaşına ve direncine göre değişiklik gösterir. Sığırların solunum yolu hastalıklarının sınıflandırılmasına yönelik yapılan çalışmalarda, fibrinli bronkopnömoniler, irinli bronkopnömoniler, interstisyel pnömoniler ve tüberkülozis ön plana çıkmaktadır (Caswel ve ark. 2007; McGavin ve ark. 2007; Çiftçi ve ark. 2015).
Sığırlarda en sık görülen pnömoni tipi olan bronkopnömoniler fırsatçı bakteriler ve mikoplazmalar tarafından oluşturulur. Oluşan lezyonlar genellikle akciğerlerin kranio ventral bölgelerinde yer alan düzensiz konsolide alanlar şeklindedir (Çiftçi ve ark. 2015).

Bronkopnömoninin erken dönemlerinde hiperemi ile birlikte bronşioalveoler boşluklarda ödem dikkati çeker. Akciğerde hasar arttıkça nötrofil granülosit, alveoler makrofaj infiltrasyonu ile fibrin oluşumu görülür (Lopez ve ark. 2017). Bronkopnömoniler; eksudat içerisinde nötrofil lökosit yoğun- 
luktaysa irinli bronkopnömoni, fibrin fazla ise fibrinli bronkopnömoni olarak isimlendirilir (Dungworth 1993; Milli ve ark. 2001).

Fibrinli bronkopnömonide plevra da yangıya katıldığı için plöropnömoni olarak da isimlendirilir (Caswel ve ark. 2007; McGavin ve ark. 2007; Çiftçi ve ark. 2015). Şiddetli konjesyon, hemoraji ve yoğun fibrin birikimi ile karakterize olan fibrinli bronkopnömonilerde kırmızı, kahverengimsi veya gri renkli hepatize alanlar görülür (Ortatatlı 1997; Caswel ve ark. 2007; Çiftçi ve ark. 2015). Fibrinli bronkopnömonilerin mikroskobisinde genel olarak bronşiyol ve alveol lümenlerinde plazma proteinince zengin SIVI, fibrin, nötrofil lökositler ile dökülmüş nekrotik hücreler göze çarpar (Lopez ve ark. 2017).

İnterstisyel pnömonide akciğer süngerimsi kıvamda, kesit yüzü kuru görünümündedir. Çoğunlukla üzerinde kaburga izleri bulunan akciğer loblarında kollaps, hepatizasyon veya konsolidasyon gözlenmez (Dungworth 1993; Çiftçi ve ark. 2015). Mikroskobik olarak alveol bazal membran ve bronşiyol duvarında hiyalin membranları görülür. Artan nötrofil granülosit ve ödem sıvısı alveol duvarının kalınlaşmasına neden olur (Lopez ve ark. 2017). Bronşiyol, bronş ve damarlar etrafındaki lenfoid dokularda hiperplazi meydana gelir. (Caswel ve ark. 2007; McGavin ve ark. 2007; Radelli ve ark. 2008; Yılmaz 2009).

Granülomatöz pnömoniler, farklı büyüklüklerde ve sayıda akciğere rastgele yayılmış, granülom oluşumu ile karakterize kronik pnömonilerdir (Jones ve ark. 1983; Ortatatlı ve ark. 1998; Akıllı ve ark. 2012). Sığırlarda granülomatöz pnömonilerin en önemlisi tüberküloz pnömonisidir (Milli ve ark. 2001; Caswel ve ark. 2007; McGavin ve ark. 2007).

Makrofajlar tarafından ortama salınan TNF $\alpha$ immun sistem hücrelerini aktive etmektedir. TNF $\alpha$ makrofajlardaki tetiklenebilir nitrik oksit sentetazı uyarır ve nitrik oksit yapımını arttırır, böylece makrofajların antibakteriyel etkinliğini arttırır (Demirtaş ve ark. 2012). TNF $\alpha$ makrofajların apoptozuna yol açarak tüberküloz etkenlerinin ortama yayılmadan yok edilmesine yardımcı olur. TNFa çok sayıda sitokin ve kemokinin salınımını arttırarak inflamasyon bölgesine lenfositlerin göçüne ve proliferasyonuna neden olur. Bu sayede granülom formasyonu oluşur ve basiller yok edilmese de bu yapı içerisinde hapsedilerek çoğalmaları ve yayılmaları önlenir (Keane ve ark. 2001). Tüberkülozda granülom, lenfositlerin makrofajları uyararak hücre içerisindeki etkeni yok edebilmesi için uygun ortam sağlar. İnfeksiyonun kontrolü için granülomun oluşumu ve devamının sağlanması esastır. Granülomların devam edebilmesi de TNFa'ya bağlıdır (Stenger ve ark. 2002; Çağlayan ve ark. 2012; Demirtaş ve ark. 2012).

Serbest radikallerin doku seviyeleri inflamasyonun gelişimi sırasında önemli artış gösterir. Membranların yapısında yer alan doymamış fosfolipitler ve kolesterol ile serbest radikaller kolayca reaksiyona girerek lipit peroksidasyonuna neden olurlar. Bu sürecin gelişimi sırasında şekillenen bir dizi reaksiyon sonucu enfeksiyonların tanısında kullanılan ve membran hasarını gösteren önemli biyolojik markerlerden MDA ortaya çıkar. MDA miktarının ölçümü ile indirek olarak lipid peroksidasyonunun derecesi hakkında bilgi sahibi olunabilmektedir (Özkan ve ark. 2003; Tüközkan ve ark. 2006).

Prokalsitonin, tiroid $C$ hücrelerinde üretilen ve kalsiyum homeostasisinde görevli kalsitonin hormonun prekürsörüdür (Assicot ve ark. 1993). Tiroid bezindeki nöroendokrin hücrelerden ayrı olarak sepsis durumlarında akciğer ve barsak gibi organlardan da salınan prokalsitonin sağlıklı bireylerde düşük seviyelerde bulunur (Baylan ve ark. 2002; Ertuğrul ve ark. 2005). Farklı yaş ve cins sığırlarda yapılan bir çalışmada ergin erkek sığırlarda kan prokalsitonin seviyesinin ortalama $53,349 \mathrm{pg} / \mathrm{ml}$ olduğu bildirilmiştir (Ercan ve ark. 2014).

Aktive monosit/makrofajlar tarafından üretilen ve düşük molekül ağırlıklı 2-amino-4-hidroksi(1'2'3' trihidroksipropil)-pteridin yapısında olan neopterin, hücre aracılı immunitenin bir belirteci olarak kabul edilir. IFN- $\gamma$ potansiyel neopterin üreticisidir ve neopterin konsantrasyonları vücut sıvılarındaki IFN- $\gamma$ varlığını gösterir (Cesur 2005). Neopterin hücre aracılı immunitenin sensitif biyobelirtecidir (Stang ark. 1998; Cesur 2005; Ercan ve ark. 2014).

Beşeri hekimlikte inflamasyonun izlenmesinde rutin olarak kullanılmakta olan biyobelirteçler, son yıllarda veteriner hekimlik alanında da kullanılmaya başlanmıştır (Hisaeda ve ark. 2001; Başoğlu ve ark. 2004; Ergönül ve ark. 2009; Özçelik ve ark. 2014). Ancak veteriner hekimlik alanında pnömonilerin tiplendirilmesi ve bu hastaların tedaviye verdiği yanıtların izlenmesinde rutin olarak kullanılabilecek biyolojik markerlere ait bilgiler sınırlıdır.

Bu çalışmada enfeksiyon hastalıkların belirlenmesinde ve prognozun değerlendirilmesinde önemli faydalar sağladığı bilinen biyolojik markerlere yönelik veteriner hekimliği alanında yapılacak çalışmalara ışık tutulması amacıyla; TNF $\alpha$, MDA, prokalsitonin ve neopterin gibi biyobelirteçlerin sığırların fibrinli ve irinli bronkopnömonilerinde, interstisyel pnömonilerinde ve tüberküloz pnömonisinde akciğer doku- 
sunda ve kan serumlarındaki düzeylerinin belirlenmesi amaçlanmıştır.

\section{Gereç ve Yöntem}

Çalışmanın materyalini mezbahaya kesim için getirilen 3270 adet 20-24 aylık sığırlardan kesim öncesi muayenede pnömoni semptomları belirlenen 296 adet sığıra ait akciğer içerisinden kesim sonrası makroskobik özelliklerine göre fibrinli bronkopnömoni, irinli bronkopnömoni, interstisyel pnömoni ve tüberküloz pnömonisi olabileceği düşünülen 25 'şer adet pnömonili akciğer dokusu oluşturmuştur.

Pnömoni semptomu belirlenen hayvanların tamamından kesim öncesi kan örnekleri alındı. Makroskobik olarak pnömoni belirlenen akciğerlerden alınan örneklerin bir kısmı ve kan serumları $-20^{\circ} \mathrm{C}$ 'de saklandı. Akciğerlerin diğer kısımları histopatolojik olarak incelendi. Histopatolojik olarak fibrinli bronkopnömoni, irinli bronkopnömoni, interstisyel pnömoni ve tüberkülozis olarak belirlenenlerle birlikte kontrol gurubundaki sağlıklı sığırlara ait $-20^{\circ} \mathrm{C}$ 'de saklanan $8^{\prime} \mathrm{er}$ adet akciğer doku ve aynı hayvanlara ait kan serum örnekleri ELISA yönteminde kullanıldı.

Akciğer örneklerinin, kendi gurupları içerisinde benzer şiddette lezyon bulunduran olgulardan alınmasına dikkat edildi.

Histopatolojik incelemeler için alınan akciğer örnekleri \%10'luk tamponlu formalin solüsyonunda tespit edildi. Tespit edilen dokular bilinen yöntemlere göre takip edilerek parafinde bloklandı. Parafin bloklardan $5 \mu \mathrm{m}$ kalınlığında alınan seri kesitler hematoksilen eozin (HE) ve Ziehl-Neelsen yöntemi ile boyanarak ışık mikroskobunda incelenerek pnömoni tipleri belirlendi.

Akciğer örneklerinden ve kan serumlarından prokalsitonin seviyeleri sandwich enzim immunoassay, TNF- $\alpha$, MDA, Neopterin seviyeleri kompetetif inhibisyon enzim immunoassay yöntemi ile ticari kitler (Cusabio, PRC) kullanılarak kit prosedürlerine uygun şekilde ELISA cihazı (Thermo Multiskan) kullanılarak belirlendi.

Elde edilen verilerin istatistik analizinde Student-T Testi ve ANOVA testlerinden yararlanıldı. Gruplar arası karşılaştırmalar SPSS 14.00 paket programı ile gerçekleştirildi (SPSS Inc., Chicago).

\section{Bulgular}

Fibrinli bronkopnömoni olarak tiplendirilen akciğerlerin interlobüler septumlarının belirginleştiği ve alacalı mermer görünümünde olduğu tespit edildi.
Mikroskobik olarak interalveoler kapillarların hiperemik olduğu alveol lümenlerinde ödem SIvısı bulunduğu ve interlobüler septumların fibrin ve ödem nedeniyle kalınlaştığı gözlendi. Bazı alanlarda alveol lümenindeki ödemin yerini fibrince zengin bir eksudatın aldığı ve eksudat içerisinde nötrofil, makrofaj ve epitel hücrelerinin bulunduğu tespit edildi (Şekil 1A). Plevrada fibrin ve ödem nedeniyle kalınlaşma dikkati çekti.

İrinli bronkopnömoni olarak tiplendirilen akciğerlerde keskin sınırlı, sert kıvamlı gri kırmızı renkli farklı büyüklükte alanlar tespit edildi. Bu alanların kesit yüzlerinde irin bulunmaktaydı. Mikroskobik olarak alveol, bronşiyol ve bronş lümenlerinin yoğun nötrofil lökositler ile dolu olduğu ve bazı epitel hücrelerinin döküldüğü dikkati çekti (Şekil 1B).

İnterstisyel pnömoni olarak değerlendirilen olgularda akciğer loblarında hacim artışı belirlendi. Kesit yüzünde, bronşiyol lümenlerinde az miktarda berrak bir sıvı bulunduğu gözlendi. Akciğerlerin kollabe olmadığı dikkati çekti. Mikroskobik olarak interalveoler septumların kalınlaşmış olduğu (Şekil 1C), bronşiyol lümenlerinin nötrofil lökosit ve dökülmüş epitel hücreleri ile dolu olduğu dikkat çekti. Bronşiolitis obliterans ve lenfoid hiperplazi tespit edildi (Şekil 1D). Bazı alveollerde hiyalin membranlara rastlandı.

Tüberküloz olarak değerlendirilen olgularda belirlenen tüberkülomların 3-4 mm çapında granülom şeklinde olduğu, bazı olgularda ise granülomların birleşerek tüberküllerin büyüklüğünün $1-3 \mathrm{~cm}$ çapa ulaştığı dikkati çekti. Kapsülle çevrili olan bu tüberküller kesildiğinde, ortada nekroz alanı ile gri veya beyaz renkli kalsifikasyonu düşündüren sert bir kitlenin bulunduğu belirlendi. Mikroskobik olarak ortada kazeifikasyon nekrozu ve kalsifikasyon alanı, çevresinde makrofaj, epiteloid hücre, langhans tipi dev hücresi (Şekil 1E), lenfosit ve plazma hücrelerinden oluşan yangısal hücre kuşağı ile en dışta fibröz bağ dokunun oluşturduğu kapsül ile karakterize olduğu görüldü. Ziehl-Neelsen yöntemi ile yapılan boyamalarda nekroz alanının çevresinde serbest veya langhans tipi dev hücresinin sitoplazmasında kırmızı renkli tüberküloz etkenleri gözlendi (Şekil 1F).

Çalışmada patolojik olarak fibrinli bronkopnömoni, irinli bronkopnömoni, interstisyel pnömoni ve tüberküloz pnömonisi olarak tiplendirilen ve kontrol grubu akciğer örneklerinin alındığı sığırlara ait kan serumlarında ölçülen TNF $\alpha$, MDA, prokalsitonin ve neopterin ortalamaları ve standart sapmaları Tablo 1 'de verilmiştir. 

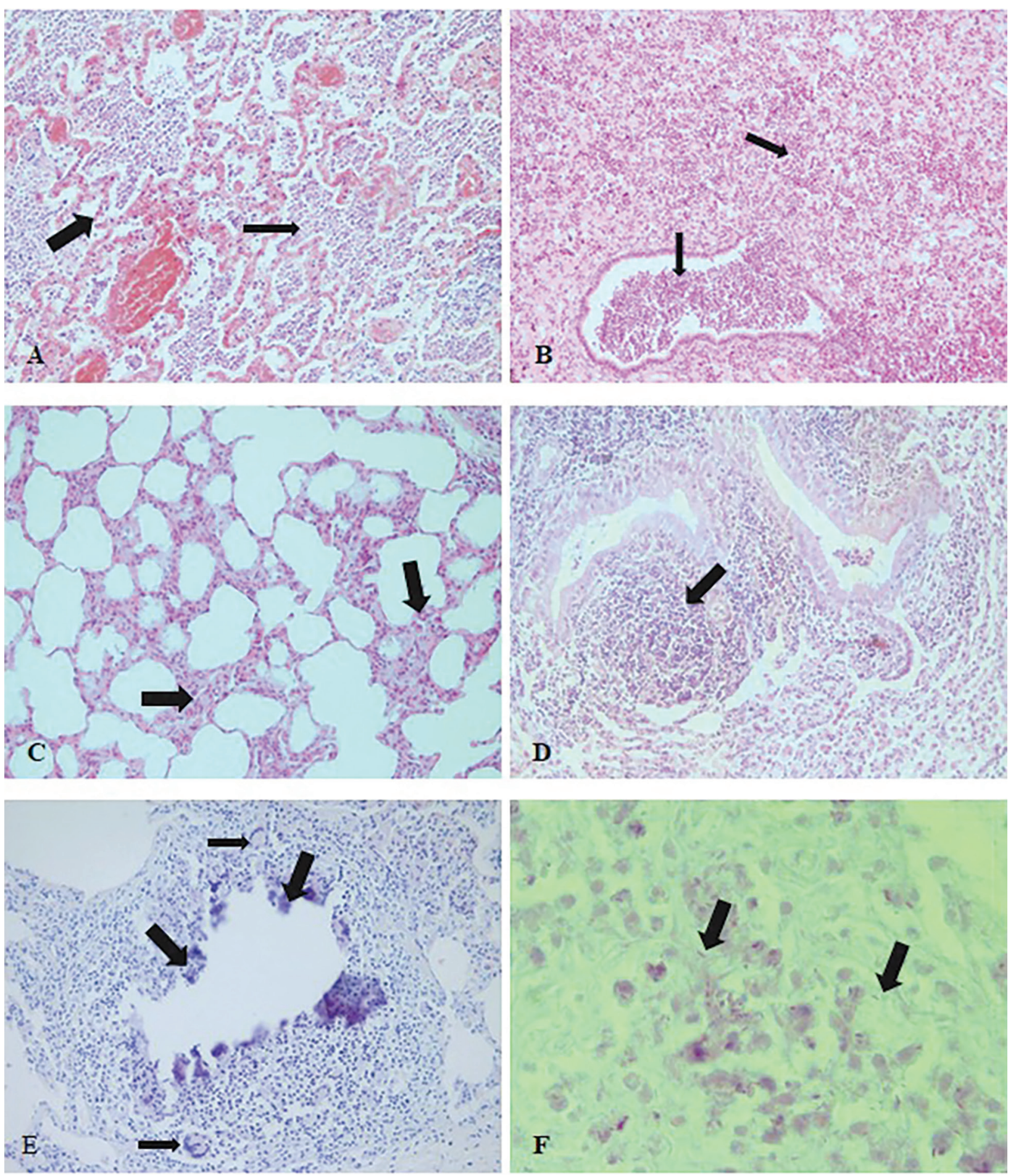

Şekil 1. A. Fibrinli bronkopnömoni, interalveoler septumda hiperemi (kalın ok), alveol lümenlerinde ödem ve nötrofil lökositler (ince ok), H.E, ×200 B. İrinli bronkopnömoni, bronşiyol ve alveol lümenlerinde nötrofil lökosit infiltrasyonu ve dökülmüş epitel hücreleri (oklar), H.E, ×200. C. İnterstisyel pnömoni, interalveoler septumda mononükleer hücre infiltrasyonları ve bağ doku artışı (ok), H.E, ×200. D. İnterstisyel pnömoni, bronşiyolitis obliterans, (ok) H.E, ×200. E. Tüberküloz pnömonisi, kazeifikasyon nekrozu ve kalsifikasyon (kalın oklar), langhans tipi dev hücresi (ince ok) H.E, ×200. F. Kazeifikasyon alanındaki aside dirençli bakteriler (oklar), Z.N, $\times 1000$ 
Çalışmada patolojik olarak fibrinli bronkopnömoni, irinli bronkopnömoni, interstisyel pnömoni ve tüberküloz pnömonisi olarak tiplendirilen ve kontrol grubu akciğer örneklerinde ölçülen TNF $\alpha$, MDA, prokalsitonin ve neopterin ortalamaları ve standart sapmaları Tablo 2'de verilmiştir.

Tablo 1. Fibrinli bronkopnömoni, irinli bronkopnömoni, interstisyel pnömoni ve tüberküloz pnömonisi olarak tiplendirilen ve kontrol grubu akciğer örneklerinin alındığı sığırlara ait kan serumlarında ölçülen TNF $\alpha$, MDA, prokalsitonin ve neopterin ortalamaları ve standart sapmaları.

\begin{tabular}{|c|c|c|c|c|c|}
\hline $\begin{array}{l}\text { Biyolojik Marker } \\
\text { (pg/ml) }\end{array}$ & $\begin{array}{l}\text { Fibrinli Bronkop- } \\
\text { nömoni }(n=8)\end{array}$ & $\begin{array}{l}\text { İrinli Bronkopnömoni } \\
(n=8)\end{array}$ & $\begin{array}{c}\text { İnterstisyel Pnömoni } \\
(n=8)\end{array}$ & $\begin{array}{l}\text { Tüberkülozis } \\
(n=8)\end{array}$ & $\begin{array}{c}\text { Kontrol } \\
(n=8)\end{array}$ \\
\hline TNF $\alpha$ & $2.38 \pm 1.44 c$ & $1,86 \pm 0,46 d$ & $2.16 \pm 1,23 c$ & $4,32 \pm 0,42 b$ & $0,84 \pm 0,16 a$ \\
\hline MDA & $986,68 \pm 48.14 c$ & $404,06 \pm 24.83 b$ & $401,48 \pm 42,62 b$ & $386,82 \pm 54,22 b$ & $250,26 \pm 54,20 a$ \\
\hline Prokalsitonin & $62,44 \pm 4,32 b$ & $128,20 \pm 7,82 c$ & $59,84 \pm 4,56 b$ & $64,63 \pm 7,62 b$ & $38,40 \pm 5,62 a$ \\
\hline Neopterin & $4,68 \pm 0,14 c$ & $4,22 \pm 0,12 c$ & $10,88 \pm 0,36 b$ & $8.26 \pm 0,40 b$ & $1,68 \pm 0,38 a$ \\
\hline
\end{tabular}

a, b, c : Aynı satırda farklı harf olan değerler arasındaki farklar istatistiksel olarak anlamlıdır $(P<0.05)$.

Tablo 2. Fibrinli bronkopnömoni, irinli bronkopnömoni, interstisyel pnömoni ve tüberküloz pnömonisi olarak tiplendirilen ve kontrol grubu akciğer örneklerinde ölçülen TNF $\alpha, M D A$, prokalsitonin ve neopterin ortalamaları ve standart sapmaları.

\begin{tabular}{|c|c|c|c|c|c|}
\hline $\begin{array}{l}\text { Biyolojik Marker } \\
(\mathrm{pg} / \mathrm{ml})\end{array}$ & $\begin{array}{c}\text { Fibrinli } \\
\text { Bronkopnömoni } \\
(n=8)\end{array}$ & $\begin{array}{c}\text { İrinli } \\
\text { Bronkopnömoni } \\
(n=8)\end{array}$ & $\begin{array}{l}\text { İnterstisyel Pnömoni } \\
\qquad(\mathrm{n}=8)\end{array}$ & $\begin{array}{l}\text { Tüberkülozis } \\
\qquad(n=8)\end{array}$ & $\begin{array}{l}\text { Kontrol } \\
(n=8)\end{array}$ \\
\hline $\mathrm{TNF} \alpha$ & $2.62 \pm 1.67 c$ & $1,96 \pm 0,11 d$ & $2.43 \pm 1,40 c$ & $4,68 \pm 0,06 b$ & $0,76 \pm 0,09 a$ \\
\hline MDA & $1108,27 \pm 68.12 c$ & $522,06 \pm 38.24 b$ & $501,82 \pm 48,71 b$ & $480,94 \pm 65,42 b$ & $420,64 \pm 35,32 a$ \\
\hline Prokalsitonin & $70,34 \pm 6,13 b$ & $318,00 \pm 8,74 c$ & $66,76 \pm 3,16 b$ & $68,23 \pm 8,80 b$ & $42,40 \pm 6,26 a$ \\
\hline Neopterin & $4,96 \pm 0,12 c$ & $4,82 \pm 0,09 c$ & $10.56 \pm 0,40 b$ & $8.34 \pm 0,51 b$ & $2,10 \pm 0,58 a$ \\
\hline
\end{tabular}

a, b, c : Aynı satırda farklı harf olan değerler arasındaki farklar istatistiksel olarak anlamlıdır $(P<0.05)$

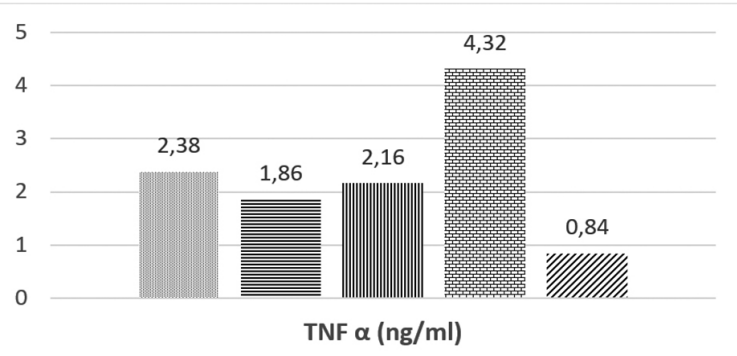

Fibrinli Bronkopnömoni $\equiv$ İrinli Bronkopnömoni IIIII Interstisyel Pnömoni 宦 Tüberküloz Pnömonisi \%, Kontrol Grubu

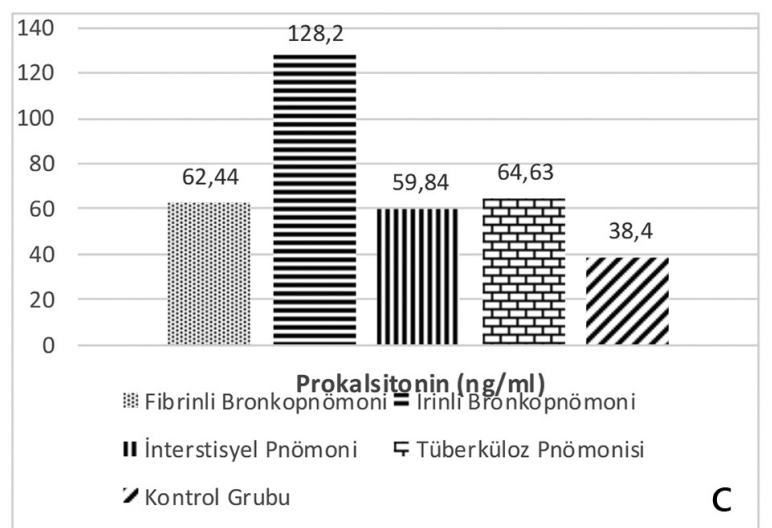

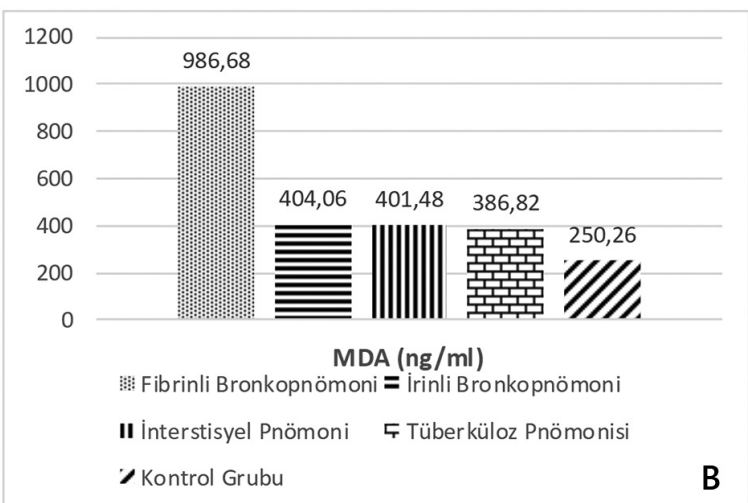

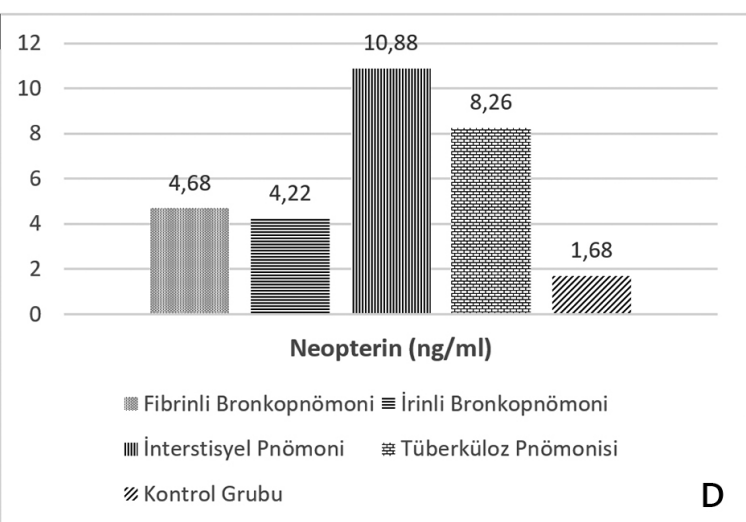

Grafik 1. Fibrinli bronkopnömoni, irinli bronkopnömoni, interstisyel pnömoni ve tüberküloz pnömonisi olarak tiplendirilen ve kontrol grubu akciğer örneklerinin alındığı sığırlara ait kan serumlarında ölçülen TNF $\alpha$ $(A), M D A(B)$, prokalsitonin (C) ve neopterin (D) seviyeleri. 
Pnömoni tiplerine göre kan serumlarında, tüberküloz pnömonili sığırlarda TNF $\alpha^{\prime}$ ıın (Grafik 1A) ve neopterinin (Grafik 1D), fibrinli brokopnömonilerde MDA'in, (Grafik 1B) irinli bronkopnömonilerde prokalsitoninin (Grafik 1C), interstisyel pnömonilerde ise neopterinin akciğer dokusunda ve kan serumunda istatistiki olarak anlamlı derecede yüksek olduğu belirlendi $(P<0.05)$.
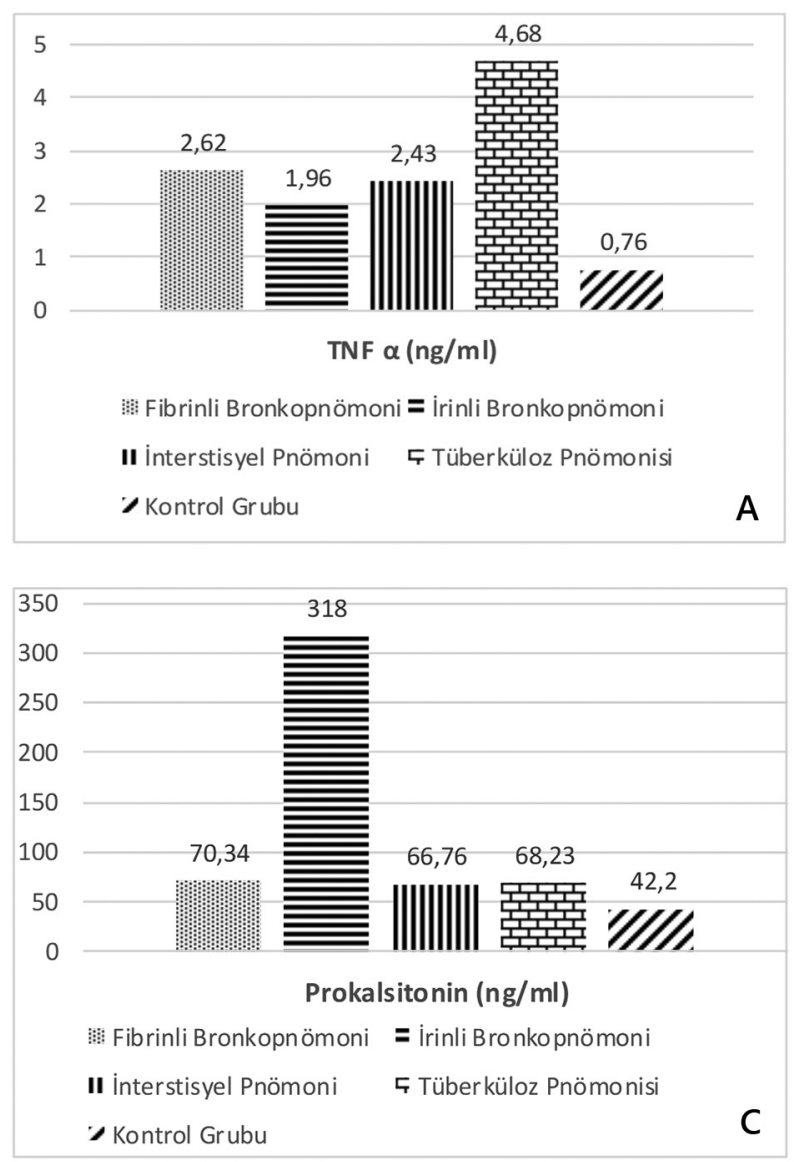

Pnömoni tiplerine göre akciğer örneklerinde, tüberküloz pnömonili sığırlarda TNF $\alpha^{\prime}$ ıı (Grafik 2A) ve neopterinin (Grafik 2D), fibrinli brokopnömonilerde MDA'in, (Grafik 2B) irinli bronkopnömonilerde prokalsitoninin (Grafik 2C), interstisyel pnömonilerde ise neopterinin akciğer dokusunda ve kan serumunda istatistiki olarak anlamlı derecede yüksek olduğu belirlendi $(P<0.05)$.

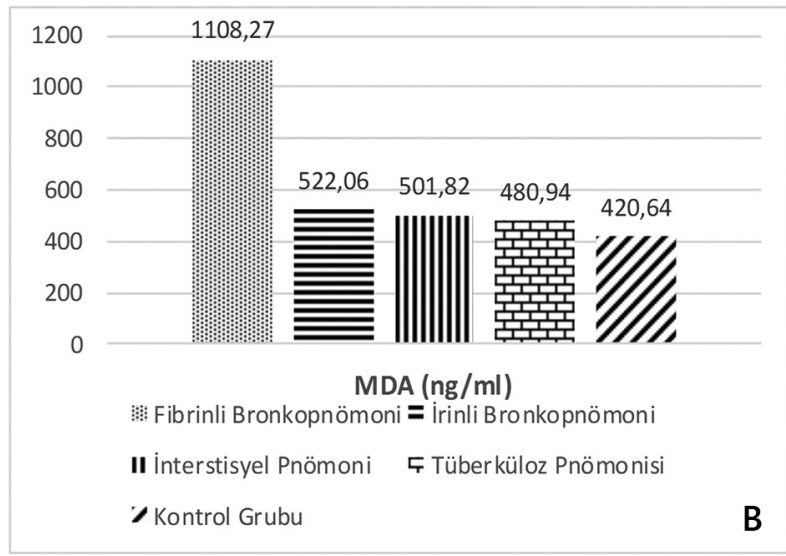

Grafik 2. Fibrinli bronkopnömoni, irinli bronkopnömoni, interstisyel pnömoni ve tüberküloz pnömonisi olarak tiplendirilen ve kontrol grubu akciğer örneklerinin alındığı sığırlara ait akciğer örneklerinde ölçülen TNF $\alpha$ $(A), \operatorname{MDA}(B)$, prokalsitonin $(C)$ ve neopterin (D) seviyeleri.

\section{Tartışma ve Sonuç}

Ülkemizde yapılan çalışmalarda besi sığırlarında görülen ölümlerin \%50-70'nin solunum sistemi hastalıklarından kaynaklandığı bildirilmektedir (Alkan ve ark. 1997; Çimtay ve ark. 2000, Çiftçi ve ark. 2015). Bu makalede, sığırlarda görülen pnömoni tipleri ile pnömonili sığırlara ait akciğer dokuları ve kan serumlarındaki TNF $\alpha, M D A$, prokalsitonin ve neopterin düzeyleri arasındaki ilişki ortaya konulmaya çalışılmıştır.
Çalışmada fibrinli bronkopnömoni, irinli bronkopnömoni, interstisyel pnömoni ve tüberküloz pnömonisi olarak tiplendirilen akciğerlerde belirlenen makroskobik ve mikroskobik bulgular pnömonilerin tiplendirildiği çok sayıda çalışmanın ve veteriner patoloji alanındaki temel kaynakların bildirdiği bulgularla benzerdir. (Gourlay ve ark. 1970; Dalgleish 1991; Dongworth 1993; Ortatatlı 1997; Milli ve ark. 2001; Caswell ve ark. 2007; McGavin ve ark. 2007; Çiftçi ve ark. 2015). 
TNF $\alpha$ reseptör kompleksi, hedef hücrede birçok biyolojik aktivitenin başlamasına neden olur. $\mathrm{TNF} \alpha$, proinflamatuvar sitokin olarak aktive T hücrelerinden ve makrofajlardan salınır (Demirtaş ve ark. 2012). Yapılan bu çalışmada fibrinli bronkopnömoni, irinli bronkopnömoni, interstisyel pnömoni ve tüberkülozis olarak tiplendirilen ayrıca kontrol grubu olarak değerlendirilen akciğer örneklerinin alındığı sığırlara ait kan serumlarında ölçülen $T N F \alpha$, seviyelerinin ortalamaları sırasıyla $2,38 \mathrm{ng} / \mathrm{ml},, 1,86 \mathrm{ng} /$ $\mathrm{ml}, 2,16 \mathrm{ng} / \mathrm{ml}, 4,32 \mathrm{ng} / \mathrm{ml}$ ve $0,84 \mathrm{ng} / \mathrm{ml}$ olarak hesaplanmıştır. Kontrol grubunda $0,84 \mathrm{ng} / \mathrm{ml}$ olarak belirlenen TNF $\alpha$ ortalaması Ercan ve ark.'ın (2014) sağlıklı sığırlarda belirledikleri seviyelerle benzerdir. Pnömoni gruplarında belirlenen TNF $\alpha$ ortalamaları kontrol grubuna kıyasla yüksek bulunmuş ve bu fark istatistiki olarak anlamlı çıkmıştır $(P<0.05)$. Pnömoni grupları kendi aralarında karşılaştırıldığında fibrinli bronkopnömoni, interstisyel pnömoni gruplarında belirlenen TNF $\alpha$ seviyesi irinli bronkopnömoni grubuna kıyasla yüksek tüberküloz gruplarında ise belirlenen TNF $\alpha$ seviyesinin diğer gruplara kıyasla oldukça yüksek olduğu dikkat çekmiştir $(P<0.05)$. Yine bu çalışmada fibrinli bronkopnömoni, irinli bronkopnömoni, interstisyel pnömoni ve tüberküloz olarak tiplendirilen ayrıca kontrol grubu olarak değerlendirilen akciğer örneklerinde ölçülen TNF $\alpha$ seviyelerinin ortalamaları sırasıyla $2,62 \mathrm{ng} / \mathrm{ml}, 1,96$ $\mathrm{ng} / \mathrm{ml}, 2,43 \mathrm{ng} / \mathrm{ml}, 4,68 \mathrm{ng} / \mathrm{ml}$ ve $0,76 \mathrm{ng} / \mathrm{ml}$ olarak hesaplanmıştır. Bu değerler klinik olarak pnömoni belirtisi gösteren sığırların kan serumunda belirlenecek TNF $\alpha$ seviyelerinin pnömonili akciğer dokularındaki düzeylerine işaret edebileceği, fakat fibrinli bronkopnömoni ve interstisyel pnömoni ayrımı için yeterli olamayacağı ancak tüberkülozisin teşhisinde klinik bulgularla birlikte değerlendirildiğinde önemli bir ipucu sağlayabileceği şeklinde yorumlanmıştır.

TNF $\alpha$ inflamasyonda doku cevabı olarak ilk salınan immun mediatörlerdendir. TNF $\alpha^{\prime}$ nın serumdaki seviyelerinin mastitis prognozunu ortaya koymada kullanılabilirliğinin araştııldığı bir çalışmada mastitisli sığırlarda serum TNFa seviyelerinin yüksek olduğu, yine süt serumlarının TNF $\alpha$ seviyesinin istatistiki olarak anlamlı düzeyde artmış olduğu rapor edilmiştir (Hiseade ve ark. 2001). Bu çalışmada belirlenen bulgulara benzer şekilde yapılan bu çalışmada da pnömoni gruplarının tamamında kontrol grubuna kıyasla $T N F \alpha$ seviyesinin yüksek ölçülmüş olması TNFa'nın sığırlarda inflamasyonu gösteren bir biyobelirteç olarak değerlendirilebileceğini göstermektedir.

Oksidatif stresin varlığı ve derecesi, lipid peroksidasyonu olarak bilinen süreçte son ürün olarak şe- killenen MDA miktarının belirlenmesiyle ortaya konabilmektedir ve artan MDA miktarı oksidatif stresin en önemli biyobelirteçlerindendir (Ünlü ve ark. 1999; Özkan ve ark. 2003; Özçelik ve ark. 2014). MDA kan plazmasında serbest oksijen radikallerini azalttığının bir göstergesi olarak yorumlanmaktadır (Özyurt ve ark. 2006). Akciğerler serbest oksijen radikallerinin etkisini önlemek ve kompanze etmek için güçlü bir antioksidan mekanizmaya sahiptir (Ünlü ve ark. 1999; Özkan ve ark. 2003). Kronik obstruktif pulmoner hastalıklı bireylerde lipid peroksidasyonun yan ürünü olan 1-hidroksinonenol ile MDA miktarındaki değişimleri belirlemek üzere yapılan bir çalışmada 1- hidroksinonenol ile MDA miktarındaki artışın akciğer fonksiyonu ile negatif ilişkili olduğu rapor edilmiştir. (Rahman ve ark. 2002). Yapılan bu çalışmada patolojik olarak fibrinli bronkopnömoni, irinli bronkopnömoni, interstisyel pnömoni ve tüberküloz pnömonisi olarak tiplendirilen akciğer örneklerinin alındığı sığırlara ait kan serumlarında ölçülen MDA seviyelerinin ortalamaları sırasıyla $986,68 \mathrm{ng} / \mathrm{ml}$, $404,06 \mathrm{ng} / \mathrm{ml}, 401,48 \mathrm{ng} / \mathrm{ml}$ ve $386,82 \mathrm{ng} / \mathrm{ml}$, kontrol grubunda ise $250,26 \mathrm{ng} / \mathrm{ml}$ olarak belirlenmiştir. Yine bu çalışmada fibrinli bronkopnömoni, irinli bronkopnömoni, interstisyel pnömoni ve tüberküloz olarak tiplendirilen ayrıca kontrol grubu olarak değerlendirilen akciğer örneklerinde ölçülen MDA seviyelerinin ortalamaları sırasıyla $1108,27 \mathrm{ng} / \mathrm{ml}$, $522,06 \mathrm{ng} / \mathrm{ml}, 501,82 \mathrm{ng} / \mathrm{ml} .480,94 \mathrm{ng} / \mathrm{ml}$ ve 420,64 $\mathrm{mg} / \mathrm{ml}$ olarak bulunmuştur. Pnömoni gruplarında ölçülen yüksek MDA seviyesi literatür ile uyumludur.

Ercan ve ark.'nın (2014) yaptıkları çalışmalarında yeni doğan, genç ve ergin sığırlarda ortalama serum MDA seviyelerini sırayla $267,4 \mathrm{ng} / \mathrm{ml}, 454,3$ $\mathrm{ng} / \mathrm{ml}$ ve $473 \mathrm{ng} / \mathrm{ml}$ olarak rapor etmişlerdir. Ercan ve ark.'nın (2014) farklı yaş ve cinsiyetteki sığırlarda belirlediği serum MDA seviyeleri yapılan bu çalışmada fibrinli pnömoni grubu dışında kalan çalışma gruplarında ölçülen değerle benzerlik göstermektedir. Ancak kontrol grubunda ölçülen değerler Ercan ve ark.'nın (2014) bildirdiği değerlerden düşüktür. Bu çalışmada kontrol grubunda ölçülen MDA seviyesi pnömoni grupların tamamından düşüktür $(P<0.05)$. Yine fibrinli bronkopnömoni grubunda belirlenen MDA değerleri de istatistiki olarak diğer pnömoni gruplarından yüksek bulunmuştur $(P<0.05)$. Elde edilen bulgular klinik pnömonili sığırlar ile sağlıklı sığırların kan MDA düzeylerini karşılaştıran Özçelik ve ark (2014)'nın çalışmalarında belirttikleri klinik pnömonili sığırlarda serum MDA düzeyleri sağlıkIı sığırlardan istatistiki olarak yüksektir bulgusuyla örtüşmektedir. Özçelik ve ark (2014)'nın bulgularına benzer şekilde yapılan bu çalışmada da pnömo- 
ni gruplarının tamamında kontrol grubuna kıyasla MDA seviyesinin yüksek ölçülmüş olması serum MDA değerlerinin sığırlarda inflamasyonu gösteren bir biyobelirteç olarak değerlendirilebileceğine işaret etmektedir.

Prokalsitoninin beşeri hekimlikte yeni doğan ünitelerinde, pnömoni, septisemi, menenjit, mantar ve parazit enfeksiyonlarında inflamasyonu izlemede ve prognozunun belirlenmesinde kullanılmaktadır. (Assicot ve ark. 1993; Demirdağ ve ark. 2003; Ertuğrul ve ark. 2005). Yapılan bu çalışmada fibrinli bronkopnömoni, irinli bronkopnömoni interstisyel pnömoni ve tüberküloz pnömonisi olarak tiplendirilen ayrıca kontrol grubu olarak değerlendirilen sığırlara ait kan serumlarında prokalsitonin seviyelerin ortalaması sırasıyla $62,44 \mathrm{pg} / \mathrm{ml}, 128,20$ $\mathrm{pg} / \mathrm{ml}, 59,84 \mathrm{pg} / \mathrm{ml}, 64,63 \mathrm{pg} / \mathrm{ml}$ ve $38,40 \mathrm{pg} / \mathrm{ml}$ olarak akciğer dokularında ise $70,34 \mathrm{pg} / \mathrm{ml}, 318,00$ $\mathrm{pg} / \mathrm{ml}, 66,76 \mathrm{pg} / \mathrm{ml}, 68,23 \mathrm{pg} / \mathrm{ml}$ ve $42,40 \mathrm{pg} / \mathrm{ml}$ olarak belirlenmiştir. Pnömoni gruplarında serum ve akciğer dokularında ölçülen prokalsitonin seviyesi kontrol grubundan istatistiki olarak yüksektir $(\mathrm{P}<0.05)$. İrinli pnömoni grubunda belirlenen prokalsitonin seviyeleri ise diğer pnömoni gruplarından anlamlı şekilde daha yüksektir $(P<0.05)$. Bu sonuçlar beşeri hekimlik alanında yapılan çalışmalarda elde edilen prokalsitonin seviyesinin yüksekliği ile inflamasyon arasında bir ilişkinin bulunduğu yönündeki kanaatle uyumlu bulunmuştur (Baylan ve ark. 2002; Demirdağ ve ark. 2003; Ertuğrul ve ark. 2005). Kandemir ve ark'nın (2003) ve Baylan ve ark'nın (2006) aktif pulmoner tüberkülozisli hastalarda serum prokalsitonin seviyelerinin artacağı, ancak prokalsitoninin spesifik olmakla birlikte zayıf sensitif bir marker olması, prokalsitonin ölçümünün duyarlıığının düşük olması nedeniyle aktif pulmoner tüberküloz tanısı için güvenilir bir test olmadığı yönündeki kanaatleri çalışmamızın bulguları ile uyumludur.

Neopterin, monosit ve makrofajların, özellikle $\gamma$-interferon tarafından uyarılması sonucu salınan pteridin yapısında bir bileşiktir. Son yıllarda çeşitli viral, bakteriyel, inflamatuar ve malign hastalıklar gibi birçok hastalıkta neopterin düzeylerinin yüksek bulunması neopterine olan ilgiyi artırmıştır. (Fuchs ve ark. 1984; Huber ve ark. 1984, Basbug ve ark. 2016; Basbug ve ark. 2020) Neopterin hücre aracılı immün yanıtın biyokimyasal belirteci olarak kabul edilmektedir (Huber ve ark. 1984; Watcher ve ark. 1989; Cesur 2005). Tüberküloz enfeksiyonu hücresel immün yanıt ile kontrol edilebilen hücre içi enfeksiyonların tipik bir örneğidir (Cesur 2005; Yüksekol ve ark. 2003). Yapılan pek çok çalışmada, reaktif oksijen metabolitleriyle etkileşimin ve oksidatif stresin yük- selmesinin neopterinle ilişkili olduğu gösterilmiştir (Yüksekol ve ark. 2003; Mohammed ve ark. 2001; Tozkoparan ve ark. 2005). Yapılan bu çalışmada fibrinli bronkopnömoni, irinli bronkopnömoni, interstisyel pnömoni ve tüberkülozis olarak tiplendirilen ayrıca kontrol grubu olarak değerlendirilen akciğer örneklerinin alındığı sığırlara ait kan serumlarında ölçülen neopterin seviyelerinin ortalamaları sırasıyla 4,68 ng/ml, 4,22 ng/ml, 10,88 ng/ml, 8,26 ng/ $\mathrm{ml}$ ve $1,68 \mathrm{ng} / \mathrm{ml}$ olarak hesaplanmıştır. Yine kan serumlarında ölçülen neopterin seviyelerine paralel olacak şekilde akciğer dokularında da sırayla 4,96 $\mathrm{ng} / \mathrm{ml}, 4,82 \mathrm{ng} / \mathrm{ml}, 10,56 \mathrm{ng} / \mathrm{ml}, 8,34 \mathrm{ng} / \mathrm{ml}$ ve 2,10 $\mathrm{ng} / \mathrm{ml}$ neopterin seviyeleri ölçülmüştür.

Yapılan bu çalışmada kontrol grubunda ölçülen neopterin seviyesi istatistiki olarak tüm pnömoni gruplarından düşüktür $(P<0.05)$. Pnömoni grupları karşılaştırıldığında tüberküloz grubu ile interstisyel pnömoni grubunun, fibrinli pnömoni grubu ile irinli bronkopnömoni grubunun benzer olduğu, interstisyel pnömoni grubu ve tüberküloz grubunda ölçülen neopterin değerlerinin oldukça yüksek olduğu belirlendi $(P<0.05)$.

Tüberkülozlu hastalarda yapılan çok sayıda çalışmada neopterin seviyesinin serum ve plevral sıvıda yüksek ölçüldüğüne dair çok sayıda rapor vardır (Mohammed ve ark. 2001; Yüksekol ve ark. 2003; Cesur 2005; Tozkoparan ve ark. 2005). Bu çalışmada da tüberkülozis grubunda hem akciğerde ve hem de kan serumlarında neopterin seviyesinin yüksek ölçülmüş olması literatür bilgileriyle uyumludur. Yine interstisyel pnömoni grubunda neopterin seviyesinin kontrol grubuna kıyasla yüksek ölçülmesi, sığırlarda interstisyel pnömonilerin etiyolojisinde çoğunlukla viral etkenlerin rol oynadığı göz önünde bulundurulduğunda, neopterin seviyesinin viral enfeksiyonlarda yükseldiğini rapor eden literatür ile örtüşmektedir (Cesur 2005).

Çalışmada pnömonili akciğer dokularında ölçülen TNF $\alpha, M D A$, prokalsitonin ve neopterin seviyeleri ile aynı gruplara ait kan serumlarında ölçülen $\mathrm{TNF} \alpha$, MDA, prokalsitonin ve neopterin seviyelerinin paralellik gösterdiği tespit edilmiştir. Bu sonuçlar, klinik olarak pnömoni belirtisi gösteren sığırlarda kan serumlarından ölçülecek TNF $\alpha, M D A$, prokalsitonin ve neopterin seviyelerinin akciğer dokularındaki düzeylerine işaret edebileceği şeklinde yorumlanabilir.

Sonuç olarak yapılan bu çalışmada sığırların tüberküloz pnömonilerinde TNF $\alpha$ ve neopterinin, fibrinli brokopnömonilerinde MDA'in, irinli bronkopnömonilerde prokalsitoninin, interstisyel pnömonilerde ise neopterinin akciğer dokusunda ve kan se- 
rumunda istatistiki olarak anlamlı derecede yüksek olduğu belirlendi $(P<0.05)$. Elde edilen sonuçlardan TNF $\alpha, M D A$, prokalsitonin ve neopterinin veteriner hekimlerin pnömonileri tiplendirmesine yardımcı olabileceği düşünülse de biyobelirteçlerin beşeri hekimlikte olduğu gibi veteriner hekimliği alanında yoğun olarak kullanılabilmesi için daha fazla çalışmaya ihtiyaç olduğu kanaatine varıldı.

Deney hayvanları kullanımı etik kurulu ve diğer etik kurul kararları ve izinler: Deney hayvanı kullanılmadığı için Etik Kurul Kararı alınmamıştır.

Maddi destek ve çıkar ilişkisi: Çalışmayı maddi olarak destekleyen kişi/kuruluş yoktur ve yazarların herhangi bir çıkara dayalı ilişkisi yoktur.

\section{Kaynaklar}

1. Akıllı H, Yoldaş A, Özmen M, Topçuoğlu H, Turut N, Tuzcu N. (2012). Çukurova Yöresinde sığırlarda görülen granülomatöz pnömonilerin etiyolojisinin histopatolojik ve moleküler yöntemlerle belirlenmesi. AVKAE Derg. 2, 1-6.

2. Alkan F, Özkul A, Karaoğlu MT, Bilde S, Akça Y, Burgu I, Yeşilbağ K, Oğuzoğlu TÇ. (1997). Sığırlarda viral nedenli solunum sistemi enfeksiyonlarının seroepidemiyolojisi. AÜ Vet Fak Derg. 44, 1-8.

3. Assicot M, Gendrel D, Carsin H, Raymond J, Guilbaud J, Bohuon C. (1993). High serum procalcitonin concentrations in patients with sepsis and infection. Lancet. 341 (8844), 515-518.

4. Basbug O, Agaoglu ZT, Tuzcu N, Coskun A, Aydogdu U, Yıgın A. (2016). Tumour necrosis factor-alpha, haptoglobin, serum amyloid $A$ and neopterin levels in cattle with lumpy skin disease. Kafkas Univ Vet Fak Derg. 22(3),417-424.

5. Basbug O, Aydogdu U, Agaoglu ZT. (2020). Neopterin and soluble urokinase type plasminogen activator receptor as biomarkers in dogs with systemic inflammatory response syndrome. J Hellenic Vet Med Soc. 71(1),1945-1952.

6. Başoğlu A, Şen I, Sevinç M, Şimşek A. (2004). Serum concentrations of tumor necrosis factor- $\alpha$ in neonatal calves with presumed septicemia. J Vet Med. 18, 238-241.

7. Baylan O, Albay A, Kısa Ö, Doğancı L. (2002). Prokalsitonin. Gülhane Askeri Tıp Akademisi Ayın Kitabı. Sayı:31.

8. Baylan O, Balkan A, Inal A, Kisa O, Albay A, Doganci L. (2006). The predictive value of serum procalcitonin levels in adult patients with active pulmonary tuberculosis. Jpn J Infect Dis. 59, 164-7.

9. Caswell JL and Williams KJ. (2007). Respiratory system. Jubb eds. Kennedy and Palmer's Pathology of Domestic Animals. $5^{\text {st }}$ ed. p.523-629.

10. Cesur S, (2005). Enfeksiyonların izleminde kullanılan bir belirleyici: neopterin. Mikrobiyoloji Bülteni. 39, 251-260.

11. Çağlayan B, Salepçi B. (2012). Anti TNF- alfa kullanan hastalarda tüberküloz sıklığı. Türk Toraks Derg. 13, 93-98.

12. Çiftçi MK, Ortatatlı M, Erer H, Hatipoğlu F, Özdemir Ö. (2015). Veteriner sistemik patoloji. 1. Cilt. Konya: Selçuk Üniversitesi Basımevi, syf.157.

13. Çimtay İ, Şahin T, Kaya NBA. (2000). Enzootik pnömonili besi sığırlarının tedavisinde kullanılan amoksisilinin etkinliğinin araştırılması. YYÜ Vet Fak Derg. 11, 113-116.

14. Dalgleish $R$, (1991). Differantial diagnosis of respiratory disease in adult cattle. In Practice. 13(6), 237-241.
15. Demirdağ K, Özden M, Gödekmerdan A, Cihangiroğlu M, Kalkan A. (2003). Sepsis olgularında prokalsitonin, tnf- alfa ve C-reaktif protein düzeylerinin değerlendirilmesi. Klinik Dergisi. 16, 21-24.

16. Demirtaş N, Ceylan E, Karadağ F, Polatıı M, Çildağ O. (2012). Adalimumab Kullanımı ile ilişkili tüberküloz pnömonisi. Tepecik Eğit Hast Derg. 22 -(3), 187-190.

17. Dungworth DL, (1993). The respiratory system. Jubb KVF, Kennedy PC, Pamer N. eds. Pathology of domestic animals. Volume 2, fourth edition. Academic Press, San Diego. p.589-613.

18. Ercan N, Tuzcu N, Başbuğ O, Gök K, Işıdan H, Oğrak YZ. (2014). The evaluation of Important biomarkers in healthy cattle. Kafkas Univ Vet Fak Derg. 20(5), 749-755.

19. Ergönül S, Aşkar T. (2009). Anaplasmosisli sığırlarda ıSı şok protein (HSP), malondialdehit (MDA), nitrik oksit (NO) ve interlökin (IL-6, IL-10) düzeylerinin araştırılması. Kafkas Univ Vet Fak Derg. 15(4), 575-579.

20. Ertuğrul Ö, Ertuğrul MB. (2005). Prokalsitonin ve enfeksiyon. Klinik Dergisi. 18(2), 59-62.

21. Fuchs $D$, Hausen $A$, Kofler $M$, Kosanowski $H$, Reibnegger $G$, Wachter H. (1984). Neopterin as an index of immune response in patients with tuberculosis. Lung. 162, 337-346.

22. Gourlay RN, Mackenzie A, Cooper JE. (1970). Studies of the microbiology and pathology of pneumonic lung of calves. $J$ Comp Pathog. 80, 575-584.

23. Hisaeda K, Hagiwara K, Eguchi J, Yamanaka H, Kirisawa R, Iwai $H$. (2001). Interferon-gamma and tumor necrosis factor- $\alpha$ levels in sera and whey of cattle with naturally occuring coliform mastitis. J Vet Med Sci. 63(9), 1009-11.

24. Huber C, Batchelor JR, Fuchs D, Hausen A, Lang A, Niederwieser D, Reibnegger G, Swetly P, Troppmair J, Wachter H. (1984). Immune response-associated production of neopterin. Release from macrophages primarily under control of interferon-gamma. J Exp Med. 160, 310-316.

25. Jones TC and Hunt RD. (1983). Veterinary Pathology. $5^{\text {th }}$ ed, Phiadelphia, USA, Lea and Febiger.

26. Kandemir Ö, Ulubaş B, Polat G, Sezer C, Çamdeviren H, Kaya A. (2003). Elevation of procalcitonin level in patients with pulmonary tuberculosis and in medical staff with close patient contact. Arch Med Res. 34, 311-4.

27. Keane J, Gershon S, Wise RP, Mirabile-Levens E, Kasznica J Schwieterman WD, Siegel JN, Braun MM. (2001). Tuberculosis associated with infliximab, a tumor necrosis factor alpha-neutralizing agent. N Engl J Med. 345, 1098-104.

28. Lopez A, Martinson AS. (2017). Respiratory System. Zachary JF. ed. Pathologc Basis of Veterinay Disease. Sixth edition, Elsevier, ST Louis.

29. McGavin MD, Zachary JF. (2007). Pathologic Basis Veterinary Disease. $4^{\text {st }}$ ed. By Mosby inc. 11830 Westline Industrial Drive St. Louis,Missori. 63146, 500-530.

30. Milli ÜH, Hazıroğlu R. (2001). Veteriner Patoloji. 2. Cilt, 2.Baskı. Ankara: Tamer Matbaacılık, syf.31-104.

31. Mohammed KH, Mobashe AA, Yousef AR, Salah A, El-Naggar IZ, Ghoneim AH, Light RW. (2001). BAL neopterin: a novel marker for cell-mediated immunity in patients with pulmonary tuberculosis and lung cancer. Chest. 119, 776-780.

32. Ortatatlı M, Çiftçi KM, Tuzcu M. (1998). Sığırlarda tüberküloz ve diğer granülomatöz pnömoniler üzerinde patolojik incelemeler. Vet Bil Derg. 14(2), 139-150.

33. Ortatatlı M, (1997). Konya Bölgesi Mezbahalarında Kesilen Besi Danalarında Pnömonilerin İnsidensi ve Patolojisi. Doktora Tezi, Selçuk Üniversitesi Sağlık Bilimleri Enstitüsü, Konya.

34. Özçelik $M$, İssi $M$, Güler $O$, Şimşek $H$, Özdemir N, Kılıç $A$ (2014). Bakteriyel pnömonili besi sığırlarında oluşan serbest 
radikal hasarının antioksidan aktivite ve bazı mineral maddeler üzerine etkisi. Erciyes Üniversitesi Veteriner Fakültesi Dergisi. 11(2), 111-116.

35. Özkan M, Yükselol İ. (2003). Nitrik oksit ve akciğer. Toraks Derg. 4(1), 88-94.

36. Özyurt B, Iraz M, Koca K, Özyurt H, Sahin S. (2006). Protective effects of caffeic acid phenethyl ester on skeletal muscle ischemia-reperfusion injury in rats. Mol Cel Bioch. 292, 197-203.

37. Radelli E, Luini M, Loria GR, Nicholas RAJ, Scanziani E. (2008). Bacteriological serological, pathological and immunohistochemical studies of Mycoplasma bovis respiratory infection in veal calves adult cattle at slaughter. Res Vet Sci. 85, 282-290.

38. Rahman I, Van Schadewijk AA, Crowther AJ, Hiemstra PS, Stolk J, Macneew DE, Boer WI. (2002). 4-Hydroxy-2-nonenal, a specific lipid peroxidation product is elevatedin lung of patients with chronic obstructive pulmonary disease. Am J Respir Crit Care Med. 166, 490-5.

39. Stang BV, Koller LD. (1998). Neopterin values in selected groups of normal animals. Res Vet Science. 65, 87-88.

40. Stenger S, Modlin RL. (2002). Control of Mycobacterium tuberculosis through mammalian Toll-like receptors. Curr Opin Immunol. 14, 452-7.
41. Tozkoparan E, Deniz O, Cakir E, Yaman H, Çiftci F, Gumus $S$, Ozcan O, Akgul OE, Bilgic H, Erbil K, Ekiz K. (2005). The diagnostic values of serum, pleural fluid and urine neopterin measurements in tuberculous pleurisy. Int J Tuberc Lung Dis. 9, 1040-5.

42. Tüközkan N, Erdamar H, Seven I. (2006). Measurement of total malondialdehyde in plasma and tissues by high- performanced liquid chromatography and thiobarbituric acid assay. $\mathrm{Fl}-$ rat Tip Dergisi. 11, 88-92.

43. Ünlü M, Akkaya A. (1999). Reaktif oksijen metabolitleri ve akciğer hastalıkları. Sol Hast Derg. 10, 207- 11.

44. Yılmaz R, (2009). Sığırlarda Mycoplasma bovis Pnömonilerinde Histopatolojik İmmunohistokimyasal Bulgular. Doktora Tezi, Uludağ Üniversitesi Sağlık Bilimleri Enstitüsü, Bursa.

45. Yüksekol I, Ozkan M, Akgul O, Tozkoparan E, Al-Rashed $M_{t}$ Balkan A, Hatipoğlu K, Bilgic H, Erbil K, Demirci N. (2003). Urinary neopterin measurement as a non-invasive diagnostic method in pulmonary tuberculosis. Int J Tuberc Lung Dis. 7, 771-6.

46. Watcher $H$, Fuchs $D$, Hausen A, Reibnegger G, Werner ER. (1989). Neopterin as a marker for activation of cellular immunity: immunologic basis and clinical application. Adv Clin Chem. 27, 81-141. 